\title{
Chemical Characteristics of Soils Based on Toposequence under Wet Tropical Area in Bukit Sarasah Padang
}

\author{
Yulnafatmawita ${ }^{\# 1}$ and Hermansah ${ }^{\# 2}$ \\ \# Department Soil Science, Faculty Agriculture, Andalas University, Padang, 25163, Indonesia \\ E-mail: ${ }^{1}$ yulna_fatmawita@yahoo.com; ${ }^{2}$ Hermankarani@yahoo.com
}

\begin{abstract}
Topography is a factor affecting soil characteristics. Chemical characteristic of a soil is a factor determining the productivity of the land. A research was conducted in Bukit Sarasah Padang, an area receiving $>5000 \mathrm{~mm}$ rainfall annually. The purpose of this research was to determine the chemical characteristics of soils at sequence topography in hill-slope of Bukit Sarasah. Soils were sampled at 3 different altitudes in the research area from $315 \mathrm{~m}-515 \mathrm{~m}$ asl with $100 \mathrm{~m}$ interval. At each location, soil samples were taken from two depths $(0-20 \mathrm{~cm}$ and $30-50 \mathrm{~cm})$ for soil chemical characteristics $(\mathrm{pH}, \mathrm{CEC}$, organic-C, N-total, $\mathrm{C} / \mathrm{N}, \mathrm{Ca}-$, $\mathrm{Mg}-, \mathrm{K}-, \mathrm{Na}-$, Al-, and $\mathrm{H}$-exchangeable). Based on the data resulted, it was found that there was a tendency of decreasing soil organic matter (SOC) content by increasing location from 315 to $515 \mathrm{~m}$ asl as well as from the top $0-20 \mathrm{~cm}$ to $30-50 \mathrm{~cm}$ soil depth. The same tendency was also found for the CEC, $\mathrm{pH}$, N-total, and $\mathrm{C} / \mathrm{N}$ ratio of the soil. On the other hand, exchangeable-Al and $-\mathrm{H}$ tended to increase by increasing elevation in Bukit Sarasah. There was no significant difference found for the concentration of exchageable cations among the elevations and between the depths. The soil chemical characteristics on the top 20 cm were generally better than those on 30-50 cm soil depth, however, different elevation did not gave significant difference of the concentration.
\end{abstract}

Keywords - Soil chemical characteristics; soil depth; topo-sequence; wet tropical area

\section{INTRODUCTION}

As land use change intensively happens in Indonesia nowadays, people have used marginal land such as sloping areas for food crop farming. Farming in sloping areas is not only risky for the erosion but also problematic to the fertility. One of several factors determining soil fertility is the chemical properties. Soil chemical characteristics are not only affected by the parent material of the soils, but also by climate, topography, organisms, and time. As other factors are the same, different soil chemical characteristics will be due to the topography.

Topography will affect temperature controlling decomposition process in soil and types of plant growth. The soils from the different elevation will have different characteristics due to different microclimate affected the soils. One of the microclimate affected soil characteristics was temperature. Temperature is climate element influencing decomposition process in soil. In fact, temperature decreases by increasing position of an area. Based on Braaks [1] air temperature decreases by $0.60 \mathrm{C}$ by each $100 \mathrm{~m}$ increase in above sea level. Soil temperature can be derived from the air temperature on which by adding $2.5 \mathrm{oC}$ to the air temperature [2]. Therefore, by increasing elevation the reaction activity will decrease. It means that area at higher elevation will receive lower reaction activity, affecting soil development process, and as a consequence, soil characteristics. As reported by Sidari et al [3] that in general soil properties and microclimate showed significant differences in Aspro Monte mountains (Italy). The difference may be attributed to topography aspect-induced microclimate differences, which causes differences in the biotic soil component, organic matter trend, affecting soil fertility.

In general, soils at higher slope will have lower fertility than at lower slope, because some soil materials from the top will be eroded and deposited in the lower part. Soil as well as the plant nutrients contained will go out of the original place. Therefore, the fertility of the soil on the lower part will be higher than that on the upper and middle slope.

Furthermore, since an area at lower elevation has higher temperature than that at higher elevation, the soil organic matter produced by crops will be decomposed faster and the nutrients will be more available for plant growth. Therefore, it is hoped that soil under lower has higher fertility than that at higher elevation.

Bukit Sarasah, a small hill in Kuranji Watershed, has elevation up to $582 \mathrm{~m}$ asl, and some has been cleared by people for farming, especially for cacao, and other perennial fruit crops. However, it is not impossible that in near future the area will be used for annual crop farming such as corn, 
soybean, and vegetable crops. Farming of seasonal crops needs good chemical properties to support their growth. Whether the chemical characteristics of the soils in the sequent topography (from 315 to $515 \mathrm{~m}$ asl) of the hilly area under wet tropical rainforest the same or not, it is interesting to know.

\section{MATERIALS AND METHOD}

The research was conducted by using survey methods and soils were sampled randomly in every a 100-meter elevation at the same slope. There were three locations (315 m, 415 $\mathrm{m}$, and $515 \mathrm{~m} \mathrm{asl}$ ) chosen for sampling the soils. Vegetation at each location was dominated by Axonophus compresses, Imperata cylindrical , Sticherus truncatus, and Melamastoma malabathricum. The higher the elevation was the less the percentage of grasses covering the soil surface. At the $515 \mathrm{~m}$ asl the soil was covered by some wide-leave trees. Disturbed soil samples were taken at $0-20 \mathrm{~cm}$ and $30-$ $50 \mathrm{~cm}$ depth in each location. Soil samples were air-dried, ground, and sieved as needed for the analyses.

Parameters analyzed were soil organic carbon (OC) (wet oxidation method), soil $\mathrm{pH}$ ( $\mathrm{pH}-\mathrm{meter}$ ), total nitrogen (digestion method), exchangeable cations (using AAS), and cation exchange capacity (CEC) (leaching using ammonium acetat at $\mathrm{pH}$ 7.0). Specifically, soil samples were separated from the fresh OM found before they were analysedPlease submit your manuscript electronically for review as e-mail attachments. When you submit your initial full paper version, prepare it in two-column format, including figures and tables.

\section{RESULTS AND DISCUSSION}

\section{A. Soil Cemical Characteristics}

Organic-C content of the soil in the hill-slope of Bukit Sarasah was affected by the elevation. The OC percentage significantly decreased by increasing elevation from 315 to $515 \mathrm{~m} \mathrm{asl}$ on the top 0-20 cm (Table 1 and Fig. 1-a), but not on the 30-50 cm depth (Fig. 1(a)). Soil OC decreased by $48 \%$ and $63 \%$ on the top $20 \mathrm{~cm}$ and $26 \%$ and $33 \%$ on the $30-$ $50 \mathrm{~cm}$ soil depth for the $415 \mathrm{~m}$ and $515 \mathrm{~m}$, respectively, compared to site $315 \mathrm{~m}$. Between both depths, it decreased by $84 \%, 77 \%$, and $72 \%$, on the $30-50 \mathrm{~cm}$ compared to the top $20 \mathrm{~cm}$ soil, respectively for altitude 315,415 , and $515 \mathrm{~m}$ asl. The decrease in the SOC might be due to the difference in OC source of the soils and OM decomposition rate. Soil at 315-m location had the highest OC content on the top 20 $\mathrm{cm}$, because the soil surface was almost $100 \%$ covered by grass (Axonopus compressus). Grass which is known has short term life, so it can produce and contribute more organic matter to soil per year compared to the higher plants or trees.

Furthermore, the activity of decomposing microbes was more intensive under grass than under forest dominated by trees. This correlates to the temperature of the soil surface, or microclimate, inducing decomposing microbial activity. Direct sunlight to soil surface under grasses had also increased the temperature of the surface soil providing better environment for microbial activity. Temperature is one of several factors affecting soil organic matter (SOM) decomposition. As reported by reference [5] amount of $\mathrm{CO}_{2}$ release, as an indicator of $\mathrm{OM}$ decomposition, from soil under higher temperature $\left(26^{\circ} \mathrm{C}\right)$ was about $164 \%$ larger than that under lower temperature $\left(19^{\circ} \mathrm{C}\right)$ at the same soil water potential. At low elevation, air and soil temperature is higher than that at higher one, as stated by Braak,1928 [1] air temperature will decrease by $0.6^{\circ} \mathrm{C}$ as elevation increases by $100 \mathrm{~m}$ asl.

Since the soils in the research location were not cultivated, SOC increased by time under grassland but not under trees in higher elevation, even though fresh OM was found in large amount there. As found by [6] that reduction of decomposition rate of $\mathrm{OM}$ sources had increased labile $\mathrm{C}$ as well as total nitrogen by increasing altitude under experimental forest in the Oregon Cascade Mountains (USA). It means that the SOM was mostly dominated by fresh OM. On the other hand, OM content of the soil in this research was classified as decomposed $\mathrm{OM}$ matter, indicated by low $\mathrm{C} / \mathrm{N}$ ratio Table 1 ).

Unlike on the top $20 \mathrm{~cm}$ soil, SOC on $30-50 \mathrm{~cm}$ depth was lower and did not significantly decrease as elevation increased from 315 to $515 \mathrm{~m}$ asl. This is due to the fact that the main source of SOC is derived from above soil surface. On the lower depth, the SOC was derived from plant roots as well as from soil microbes and the root exudates. Since the activity of microbes was higher under higher temperature (lower elevation), while more roots were found under higher elevation (derived from tree roots), the total contribution of both to SOC was not significantly different.

As SOC content, total nitrogen (total-N) of the soil performed the same tendency, it decreased by increasing elevation (Tabel 1). This was due to fact that either OC or

TABLE I

CHEMICAL CHARACTERISTICS OF SOILS ALONG TOPOSEQUENCE IN BUKIT SARASAH PADANG AT 0-20 CM DEPTH

\begin{tabular}{|l|c|c|c|}
\hline Soil Parameter & $315 \mathrm{~m}$ & $415 \mathrm{~m}$ & $515 \mathrm{~m}$ \\
\hline Soil pH-H2O (1:1) & 4.85 & 4.58 & 4.19 \\
\hline Soil pH-KCl (1:1) & 3.62 & 3.64 & 3.57 \\
\hline Organic-C (\%) & 4.08 & 2.11 & 1.50 \\
\hline N-total (\%) & 0.46 & 0.27 & 0.16 \\
\hline C/N Ratio & 8.96 & 7.82 & 5.49 \\
\hline Exchangeable-Na (me/100 g) & 5.08 & 5.04 & 4.80 \\
\hline Exchangeable-K (me/100 g) & 2.36 & 2.78 & 2.58 \\
\hline Exchangeable-Ca (me/100 g) & 1.05 & 1.25 & 1.09 \\
\hline Exchangeable-Mg (me/100 g) & 1.83 & 2.31 & 2.06 \\
\hline Exchangeable-Al (me/100 g) & 2.40 & 2.60 & 7.00 \\
\hline Exchangeable-H (me/100 g) & 0.18 & 0.29 & 1.47 \\
\hline Soil CEC (me/100 g) & 28.04 & 13.64 & 11.43 \\
\hline Al-saturation $(\%)$ & 8.56 & 19.06 & 61.26 \\
\hline
\end{tabular}

$\mathrm{N}$ was originated from the vegetation growing on the soils. The higher the SOC content is the higher the $\mathrm{N}$ content of the soil since the OM source is the same. For both depths, the N-total (Fig. 1(b)) of the soilsfollowed the tendency of SOC. 
High OC content in a soil will cause in high cation exchange capacity which is able to adsorb more cations and reduce the leaching process of basic cations. More basic cations in soil colloids and soil solution will bring the soil becomes less acidic. Therefore, the soil $\mathrm{pH}$ (Tabel 1 and Fig 1(c)) followed the tendency of OC and N-total concentration within the soil depths. However, the soil $\mathrm{pH}$ at lower depth $(30-50 \mathrm{~cm})$ does not significantly different from the top 20 $\mathrm{cm}$. This probably was due to leaching process of the cations. As the area is located under wet tropical rainforest with annual temperature $>5000 \mathrm{~mm}$, the leaching process becomes intensive. This is proved by the concentration of some basic cations, especially $\mathrm{Na}, \mathrm{K}, \mathrm{Ca}$, and Mg (Fig. 1(g), 1(h), 1(i), and 1(j)) which was not significantly different from the ones on the upper depth.

High OC at the $315 \mathrm{~m}$ site contributed to more negative charges (CEC) to the soil. This CEC decreased as the $\mathrm{pH}$ was lower at higher elevation (415 and $515 \mathrm{~m}$ ). As stated by [7] that besides mineral colloid (clay), the CEC in tropical soil can be derived from organic colloid (humus) which has $\mathrm{pH}$ dependent charge. This meant that the soil is able to retain more nutrients in form of cations before crops uptake them, and the efficiency of fertilizer use increases at high $\mathrm{pH}$. The CEC values of the soil decreased by $51 \%$ and $59 \%$ on the top $20 \mathrm{~cm}$ and by $25 \%$ and $15 \%$ on the $30-50 \mathrm{~cm}$ depth at the $415 \mathrm{~m}$ and $515 \mathrm{~m}$ respectively compared to the $315 \mathrm{~m}$ site. Between both depths, the decrease in CEC (Fig. 1(d)) tended to be larger as the elevation increase from 315 to $515 \mathrm{~m}$ asl. Soil CEC on the $30-50 \mathrm{~cm}$ depth decreased by $50 \%, 33 \%$, but increased by $5 \%$ at the 315,415 , and $515 \mathrm{~m}$ $a s l$, respectively, compared to the top $20 \mathrm{~cm}$.

Reference [6] also reported that soil $\mathrm{pH}$ at Oregon Cascade Mountains was significantly lower on the higher elevation. Reference [3] found that topography in Aspromonte Mountains in Southern Italy gave significant differences in soil properties. The differences could be due to differences in microclimate induced by topoghraphy, which alter the OM trend, affecting soil fertility. Reference [8] reported that interactions between topography and land use in south-western China controlled soil $\mathrm{pH}, \mathrm{OM}, \mathrm{N}, \mathrm{P}$, $\mathrm{Ca}$, and $\mathrm{Mg}$. Reference [9] found that topography was an important factor affecting soil properties. Reference [10] reportd that SOM, total-N (TN), total-P (TP), available N (AN), and available P (AP) showed an increase values from upper to foot slopes from a specific land use structure (fallow land-shrub land-fallow land-cropland-woodlandorchard) in the loess plateau, China.

As SOC, and other soil chemical properties such as Ntotal, CEC, and soil $\mathrm{pH}$ also tended to decrease by increasing elevation, but concentration of $\mathrm{H}^{+}$(Fig. 1(e)) and Alexchangeable (Fig. 1(f)) showed an opposite tendency. Soil pH decreased by $6 \%$ and $14 \%$ on the top $20 \mathrm{~cm}$ and by $9 \%$ and $16 \%$ on the $30-50 \mathrm{~cm}$ depth at the $415 \mathrm{~m}$ and $515 \mathrm{~m}$ compared to $315 \mathrm{~m}$ site. Between both depths, it did not show a significant difference in each site.

Highest soil $\mathrm{pH}$ or lowest $[\mathrm{H}]^{+}$at $315 \mathrm{~m}$ asl was probably associated with higher SOC at the research location. Higher $\mathrm{pH}$ value under $315 \mathrm{~m}$ elevation causes $\mathrm{Al}$ and $\mathrm{Fe}$ precipitated, so less $\mathrm{H}+$ was found in soil solution. Increasing $\mathrm{pH}$ value as increasing $\mathrm{SOM}$ also reported by [11], in which soil pH increased from 5.86 to 6.03 (in 2007) and from 5.43 to 6.20 (in 2008) by addition of 10 ton manure/ha on Alfisols ( (Oxic tropuldalf) ) in Nigeria. Reference [12] also found that increasing soil $\mathrm{pH}$ as OM added to Reiff loam soil (coarse-loamy, mixed, nonacid, thermic Mollic Xerofluvents) and Yolo silt loam soil (finesilty, mixed, nonacid, thermic Typic Xerorthents) in California, USA. During their research, soil $\mathrm{pH}$ value consistently increased for 8 years (1988-1996) research. They, furthermore, explained that one of the factors causing an increase in soil $\mathrm{pH}$ as $\mathrm{OM}$ added to soil was due to contribution of cations from OM decomposition to the soil.

Contrary to the $\mathrm{pH}$ values, the exchangeable aluminum increased under higher elevation. Al-saturation increased by 2.23 times at the $415 \mathrm{~m}$ and 7.16 times at the $515 \mathrm{~m}$ on the top $20 \mathrm{~cm}$ and by 1.74 times at the 415 and by 2.51 times at the $515 \mathrm{~m}$ on the $30-50 \mathrm{~cm}$ soil depth compared to those at the $315 \mathrm{~m}$ location. Higher Al-saturation percentage on higher locations (415 and $515 \mathrm{~m} \mathrm{asl}$ ) seemed to be due to lower soil $\mathrm{pH}$ as well as low SOM content which could deactivate the $\mathrm{Al}$ cations. Between both depths in each location it was found an increase in Al-saturation on the 30$50 \mathrm{~cm}$ by 1.91 times, 1.49 times, and decrease by 0.67 times for location 315,415 , and $515 \mathrm{~m}$, respectively, compared to the Al-saturation on the top $20 \mathrm{~cm}$ soil surface.
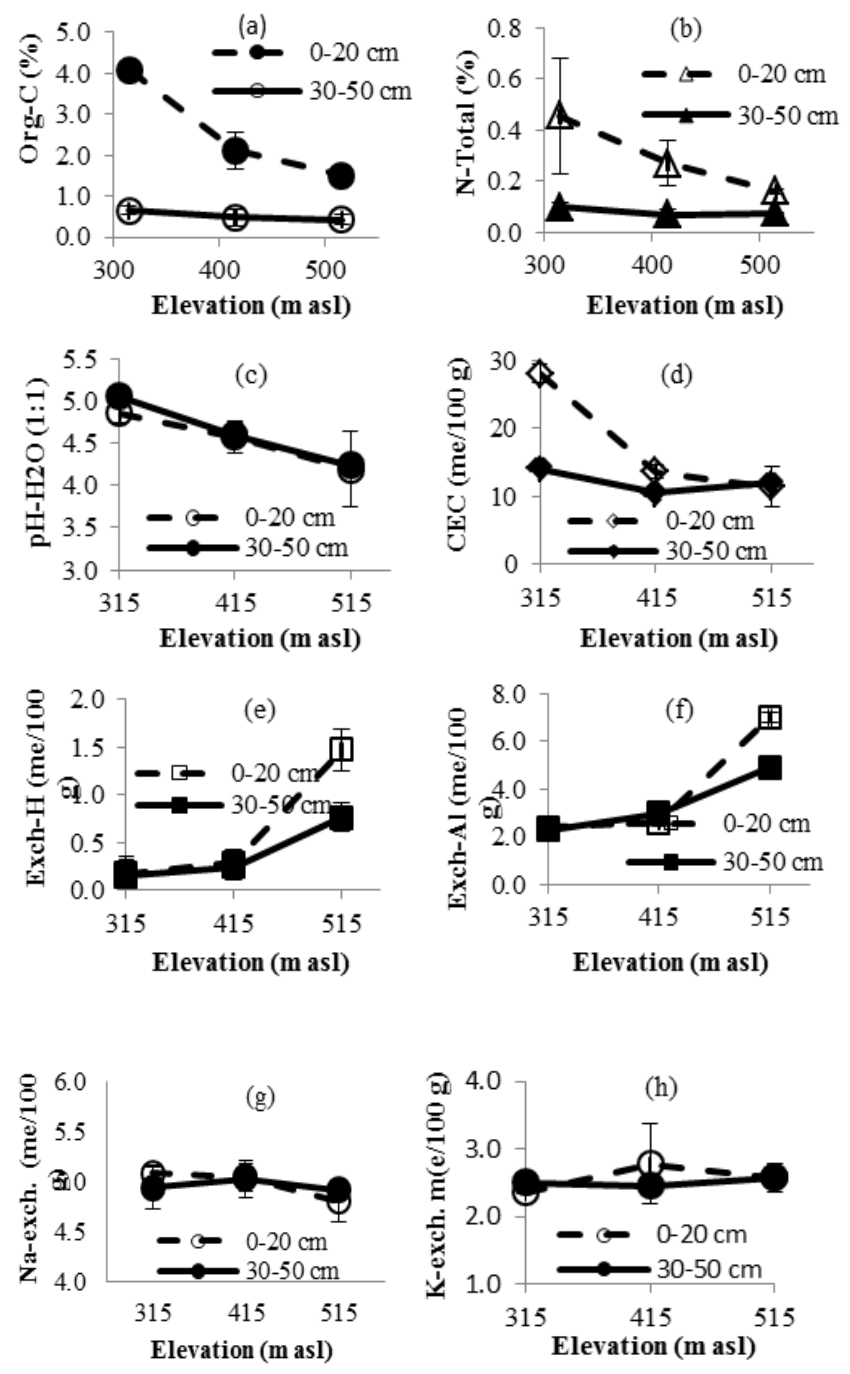

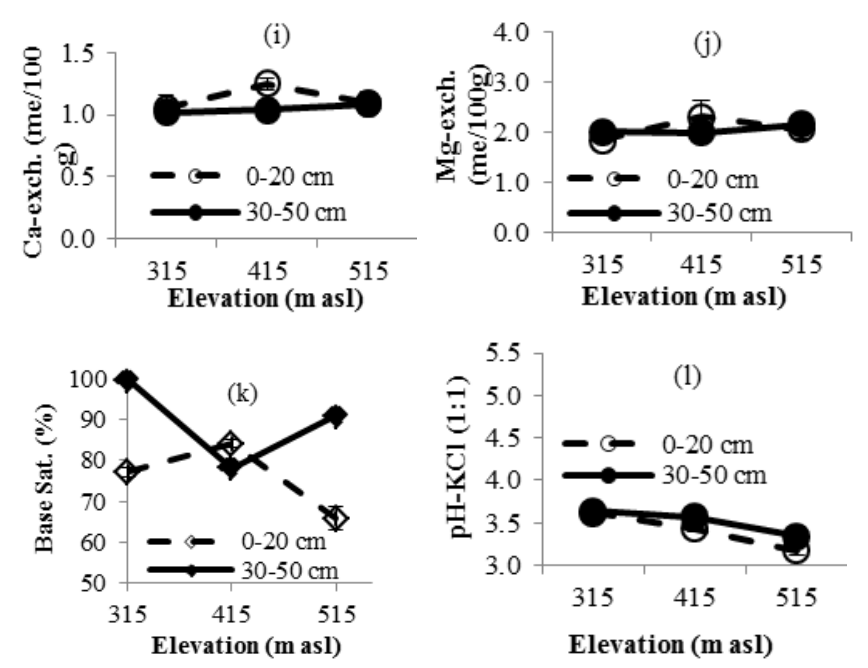

Fig. 1 Soil chemical characteristics $(a=O C, b=T o t-N, c=p H ~ H 2 O, d=C E C$, $\mathrm{e}=\mathrm{H}$-exch, $\mathrm{f}=\mathrm{Al}-\mathrm{exch}, \mathrm{g}=\mathrm{Na}-\mathrm{exch}, \mathrm{h}=\mathrm{K}$-exch, $\mathrm{i}=\mathrm{Ca}-\mathrm{exch}, \mathrm{j}=\mathrm{Mg}$-exch, $\mathrm{k}=$ base sat, $\mathrm{l}=\mathrm{pH} \mathrm{Kcl}$ ) at different altitude under wet tropical area from two $(0-20 \mathrm{~cm}$ and $30-50 \mathrm{~cm})$ depths

\section{B. Relationship Between soil $\mathrm{pH}$ and Exchangeable Cations}

Decomposed organic matter will contribute plant nutrients such as $\mathrm{N}, \mathrm{Ca}, \mathrm{Mg}$, dan $\mathrm{K}$ to the soil, therefore, higher $\mathrm{OM}$ content of a soil will contribute to high soil cations. As the soil $\mathrm{pH}$ increased, soil CEC also increased due to organic colloids. Therefore, the cations ( $\mathrm{Ca}, \mathrm{Mg}$, and $\mathrm{K}$ ) were adsorbed on colloid surface and finally contributed to higher base saturation (Fig. 1(k)) of the soils.

However, there was no significant difference of the cations $(\mathrm{Na}, \mathrm{K}, \mathrm{Ca}, \mathrm{Mg})$ found in the research site $(315,415$, and $515 \mathrm{~m}$ asl) even though the soil had different $\mathrm{pH}$ values. This was probably due to the fact that soil $\mathrm{pH}$ was generally classified as acid $(\mathrm{pH}<7)$ that cations were equally affected. The exchangeable cations were not significantly different. Since the soil was dominated by Ultisols (high clay content with low SOM on the soil surface, except at 315 maltitude covered by pasturet), the cations were mainly contributed by the mineral fraction of the soils.

There was no correlation found between soil $\mathrm{pH}$ and exchangeable cations either based on the elevation or based on the soil depth. Different soil $\mathrm{pH}$ did not alter exchangeable cations (Fig.2(a)). This seemed to be due to the difference in soil $\mathrm{pH}$ among the sites and between the depths was not quite high. All soil $\mathrm{pH}$ values in the research sites were classified into acid (between 4.19 to 5.06 or < 6). This agreed with the results reported by [13].

The cations in the research site were mostly leached due to high annual rainfall, because the soils (Ultisols) were dominated by kaolinite clay mineral, having low permanent charge density. Since the solum of the soil $>100 \mathrm{~cm}$ in average, the leaching cations could go far under rooting zone $(0-50 \mathrm{~cm})$. Therefore, the amounts of cations were not significantly different either between top $20 \mathrm{~cm}$ and 30-50 $\mathrm{cm}$ soil layers or among the elevation $(315 \mathrm{~m}-415 \mathrm{~m}-515$ $\mathrm{m}$ asl).

Based on Table 1, there was no significant difference for exchangeable basic-cations ( $\mathrm{Ca}, \mathrm{Mg}, \mathrm{Na}$, and $\mathrm{K}$ ) among the research sites and between both depths in each site. Even though the soil $\mathrm{pH}$ and the soil OC decreased by increasing elevation (Figure 1(d) and 1(a)), the exchangeable cations were generally the same.

Soil $\mathrm{pH}$ value did not affect the concentration of exchangeable cations (Fig. 2(a)). This might be due to the parent material of the soil which is acidic and the soil is classified into to Ultisols (Wakatsuki et al, 1986) which has low base saturation. A part from it, high annual rainfall caused more cations leached by time. Since the area has been well developed and has reached the final decomposition process, the solum was quite thick. It is thought that both depths $(0-20$ and $30-50 \mathrm{~cm})$ were still at A horizon from which the cations were leached into deeper depth.

Even though the exchangeable basic-cations were not significantly different among elevations and between depths, The exchangeable $\mathrm{Al}$ and $\mathrm{H}$ as well as the percentage of Alsaturation increased by increasing elevation for both depths. Increasing $\mathrm{Al}$-saturation by increasing elevation was due to the fact that the Al-exchangeable (Fig. 1(f)) increased as the numerator and the CEC as the denominator decreased. Both exchangeable $\mathrm{Al}$ and $\mathrm{H}$ were highly correlated $(\mathrm{R} 2=0.82$ and 0.88 ) to the $\mathrm{pH}$ values of the soil (Fig. 2(b)).
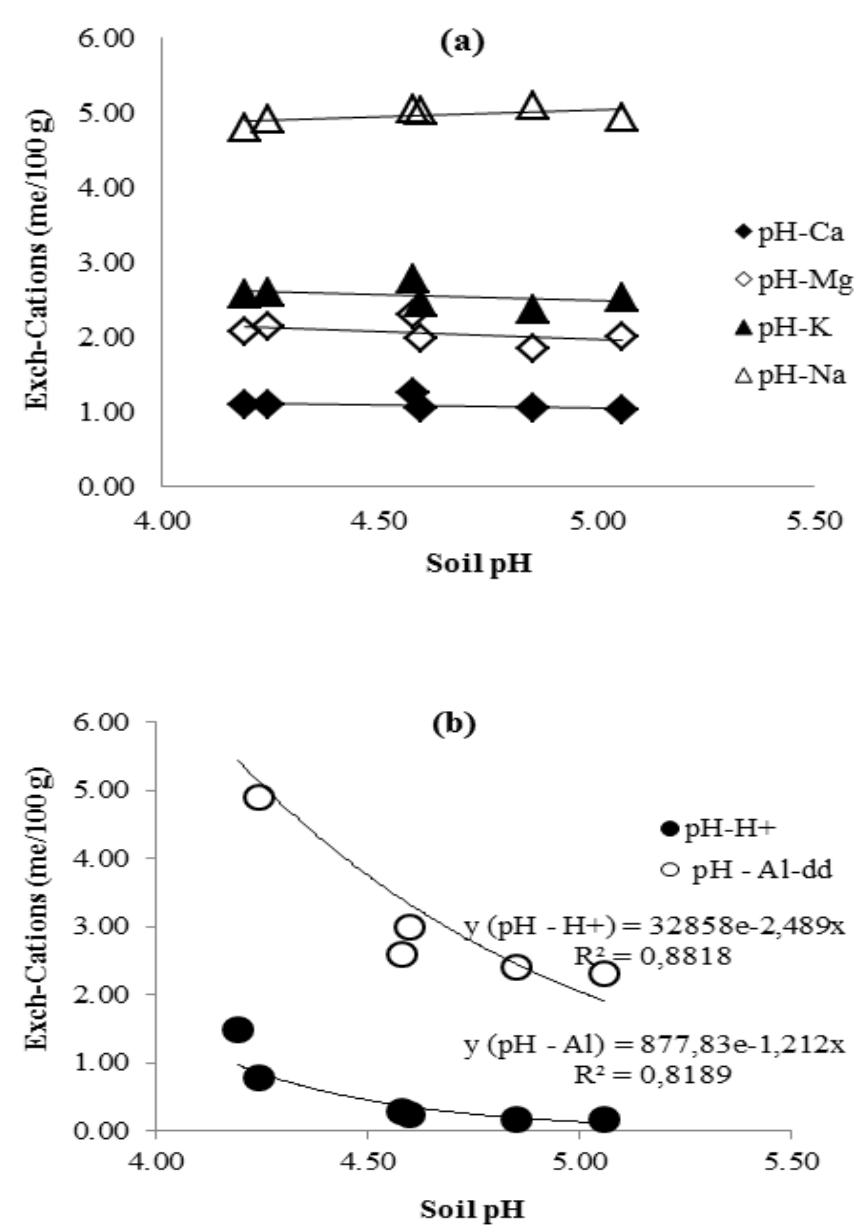

Fig. 2. Relationship between soil $\mathrm{pH}$ and exchangeable basic (a) and acidic (b) cations 


\section{IV.CONCLUSIONS}

Based on the data analysed, the chemical properties of the soil from different altitudes in a wet tropical area in Bukit Sarasah Padang, West Sumatra, Indonesia, can be concluded that the soil reaction was considered acidic (generally $<5.0$ ), high acidic cations $\left(\mathrm{Al}_{3}{ }^{+}\right.$and $\left.\mathrm{H}^{+}\right)$and low soil nutrient content, especially basic cations. Based on these chemical properties, the areas $(315,415,515 \mathrm{~m} \mathrm{asl})$ were not recommended for annual crop farming, otherwise there are external inputs to meet crop needs as long as the action is not against conservation rule.

\section{ACKNOWLEDGMENT}

Authors say thanks to The General Director of Higher Education of Indonesia for the research funding and to Anditias Ramadhan and Arief Farma for the data collecting.

\section{REFERENCES}

[1] B.Lakitan. Dasar Klimatologi. PT Ragagrafindo Persada. 1994, Jakarta.(Indonesian)

[2] Djunaidi. and S. Rachim. Morfologi dan klassifikasi tanah. Jurusan Tanah Fakultas Pertanian Bogor. 2002, 177 pages (Indonesian)

[3] M. Sidari, G. Ronzella, G. Vecchio, and A. Muscolo. Influence of slope aspect on soil chemical and biochemical properties in a Pinus laricio forest ecosystem of Aspromonte (Southern Italy). Eur J Soil Biol. 44 (2008):364-372. doi:10.1016/j.ejsobi.2008.05.001

[4] A.Rasyidin. The method for measuring rates of weathering and rates of soil formation in watershed. Disertase.Tottory Univ. Japan, 1994,110 p.
[5] Y.Yulnafatmawita, H.B.So, N.W. Menzies, and R.C.Dalal. CO2 emission from different soil fractions following physical disruption: Implication for tillage practices. The 16th Triennial ISTRO Conference 13-18 July 2003. Brisbane Australia

[6] G.Uehara and G.Gillman. 1981. The Mineralogy. Chemistry. and Physics of Tropical Soil with Variable Charge Clay. (1981) Westview Press. Boulder Colorado USDA.

[7] P.T.Guo, W.Wu, H.B. Liu, and M.F.Li. Effects of land use and topographical attributes on soil properties in an agricultural landscape. Soil Research Vol. 49 (7) 2011: 606-613, http://dx.doi.org/10.1071/SR11134

[8] J. Seibert, J. Stendahl, and R. Sørensen. Topographical influences on soil properties in boreal forests. Geoderma 141 (2007): 139-148 doi:10.1016/j.geoderma.2007.05.013

[9] J.Wang. B.J.Fu, Y.Qiu, and L.D.Chen. Soil nutrients in relation to land use and landscape position in the semi-arid small catchment on the loess plateau in China. J.Arid Environ 48 (2001):537-550 doi:10.1006/jare.2000.0763

[10] E.O.Adeleye, L.S. Ayeni, and S.O. Ojeniyi. Effect Of Poultry Manure On Soil Physico-Chemical Properties. Leaf Nutrient Contents And Yield of Yam (Dioscorea rotundata) on Alfisol In Southwestern Nigeria. J. American Sci. 2010, Vol.6 (10): 871-878,. http://www.Americanscience.org- ISSN: 1545-1003

[11] M.S. Clark, W.R. Horwath, C. Shennan, and K.M. Scow. Changes in Soil Chemical Properties Resulting From Organic And Low-Input Farming Practices. Agron. J. 1998. Vol. 90:662-671. doi:10.2134/agronj1998.00021962009000050016x

[12] N.Hakim, Herviyanti, dan A. Meirita. Pengaruh Penambahan Titonia Terhadap Sifat Kimia Ultisol Dan Hasil Tanaman Kedelai Pada Musim Tanam Ke Tiga. J. Solum Vol. III No. 2 Juli 2009: 10-21 (Indonesian) http://repository.unand.ac.id/21266/1/Laporan-HIBER2009.pdf

[13] T.Wakatsuki, A. Saidi, and A.Rasyidin. Soil in topsequence of the gunung Gadut tropical rainforest, West Sumatra. South East Asian Studies 24(3) $1986: 243-262$ 